\title{
エクスパートに聞く 3
}

\section{Broca 野・Wernicke 野・弓状束の真実?}

\author{
河内十郎*
}

\begin{abstract}
要旨：Brodmannの 44 野と 45 野とからなるとされている Broca 野は, Broca が構音言語機能の座とした にもかかわらず, 今日では言語野とされており, Broca 野が実際に構音言語機能を持つのかどうかはまだ 明らかではない。Wernicke 野 (上側頭回後部) も, Wernickeはことばの聴き取りを意味する言語の聴覚 心像の座としたにもかかわらず, 言語理解の座として議論されることが多く, Wernicke 野の真の機能も 明らかではない。ヒトの脳では長連合線維を確認する手段がないなかで Broca 野と Wernicke 野とを結ぶ とされた弓状束は, 拡散テンソル画像（Diffusion Tensor Imaging：DTI）の出現によって種々検討されて いるが, 起始部と終止部を決定できないなどの DTI の致命的な欠陥のために, 結果は混乱を呈している。
\end{abstract}

(高次脳機能研究 37 (2)：201～204, 2017)

Key Words : Broca 野, 構音言語機能, Wernicke 野, 弓状束, DTI

Broca's area, articulate speech, Wernicke's area, arcuate fasciculus, DTI

\section{はじめに}

脳前部の Broca 野と脳後部の Wernicke 野とを弓 状束が結んでいるとする Wernicke が提唱し Geschwind が復興させた古典論の言語処理モデルは, 近年さまざまな点で問題が指摘されており, 真実が 何処にあるかがはっきりしない状態にあるといって も過言ではない。本稿では, そうした問題点を考え ていくことにしたい。

\section{I . Broca 野の真実?}

Broca 野は, 1861 年にBroca が, 発話の障害を呈 した 2 例の患者 Leborgne と Lelong の共通病巣が 左半球の第三前頭回後部にあったことから, その部 位を構音言語機能の座と規定したことに始まる。 Broca 野の正確な範囲については異論があるもの の, 今日では Brodmannの 44 野と 45 野とする立 場が一般的である (Tremblay ら 2016 など)。

Broca は, 普遍的言語機能と構音言語機能とを明 確に区別し, Leborgne と Lelongの病態を, 言葉を 発する機能（構音言語機能）のみの岥失として aphemia と名付け, aphemia を「言葉を発する為に辿 るべき運動の記憶の障害」と規定している。これは今 日の用語でいえば, 発語失行 (apraxia of speech : AOS）に近い概念で, Brocaは Broca 野を損傷によ り aphemia が起こる部位としたので, Broca野は
言語野ではないことになる。しかし，その後の失語 学は, Broca 野を運動性言語中枢と呼ぶなど言語野 とみなしており, 膨大な数に上る近年の機能画像研 究も, さまざまな言語課題での Broca 野の活性化 を明らかにしている。さらに最近では, Broca野は 行為など言語以外の機能も関係しているとされてい る(岩田ら 2011)。

このように, Broca 野が持つことが明らかにされ ている多様な機能に加えて, さらにBrocaの主張 する構音言語機能も含まれているのかが問題となる が, Penfieldら (1959) などが, Broca 野の電気刺 激では失語停止（aphasic arrest）は起きるが発語 停止（speech arrest）は起きないとしたことなどか ら,「Broca 野が言語表出機能にとって近傍の構造 よりも重要であるという確固たる根拠はない」（西 尾ら 2011) とまで主張されている。しかし一方では, 単音節単語復唱時にBroca 野は単語提示後運動野 より先に活性化する（Flinkerら 2015）, 覚醒下開 頭受術者で系列語発話時にBroca 野を冷却すると 発話の時間的変化が起き, 発話運動領域の冷却では 声の質の変化が起こる（Longら 2016）など, Broca 野が発話運動領域より一段高次のレベルで発 話に関与していることを示唆する結果も報告されて いる。さらに発話運動の障害に当たるどもり（stuttering）が 44 野と運動前野との線維結合の異常が 原因とする主張（Chang ら 2011）もあり, Broca 
野が構音言語機能を持つかどうかの問題は，まだ決 着がついていないのが現状である。

44 野は，第 IV 層が認められるが発達が悪い不全 顆粒皮質で尾側に位置する無顆粒皮質である運動野 に近く, 45 野は吻側の前頭連合野ほどではないが 第 IV 層が発達した顆粒皮質で連合野に近い。また, Braak（1984）は, 厚い切片のアルデヒド・フクシン 染色によって, 44 野の第吕層には大型錐体細胞が 存在するが 45 野の第正層にはそうした大型の錐体 細胞はないことを明らかにしている。さらに 44 野 と 45 野は線維連絡も異なり, 44 野は頭頂・側頭領 域と主として背側経路を介して連絡し，45 野は腹 側経路を介している（Freyら 2008 など）。こうし た構造上の違いがある 44 野と 45 野を，一括して議 論して良いのかどうかも問題である。

Broca 野近辺の線維結合を拡散テンソル画像 (Diffusion Tensor Imaging：DTI）で検討した Lemaire ら（2013）は, 44 野は尾側の 6 野と U 線維で結ばれ, 45 野は吻下側の眼窩部とU 線維で結ばれているこ とを明らかにしたが, 44 野と 45 野との線維連絡に ついては何も述べていない。さらにBrown ら (2014) も，45 野が 6 野とU 線維で結ばれていることを明 らかにしているが, ここでも 44 野と 45 野との関係 については何も記述されていない。44 野と 45 野は 隣接しているので当然 U 線維で連絡していること が考えられるが，DTIで他の領野とを結ぶ U 線維 が捉えられているのに，44 野と 45 野の間のU 線維 が記述されていないのは，あるのが当然なのでわざ わざ記述されなかった可能性もあるが，U線維が捉 えられなかったことを示しているとも考えられる。 サルの 45 野にトレーサーを注入した研究 (Yeterian ら 2012 など）では，44野にも到達していることが 示されているが，前頭葉と頭頂葉の線維結合をまと めた図（Marguliesら 2013）では, 44 野と 45 野 との間の連絡は示されていない。このようにヒトと サルの 44 野と 45 野の間の線維連絡については, な いことを明示した報告はないが，あることを明示し た報告もないのが現状で，真実がどちらなのかは明 らかではない。

\section{Wernicke 野の真実 ?}

古典論では Wernicke 野は上側頭回後部とされて いるが, Wernickeはそこをことばの聴き取りに関 与する言語の聴覚心像の座としており, Lichtheim-
Wernicke の失語図式からも明らかなように, この 部位を言語理解の中枢と規定したわけではない。し かしその後の失語研究では, 上側頭回後部の機能を 語音認知とする立場もあるものの，この部位を損傷 により言語理解の障害が起こる部位として議論が進 められていることが多い（Bogenら 1976 など）。 Wernicke 失語がことばの理解の障害を示すことは 事実だが，その原因は，復唱ができないことからも 明らかなように, ことばの聴き取りの悪さにあるこ とも考えられる。この点に関しては, Binder (2003) が, Henschen が 1920 年代の初めに, 上側頭回限局 病変 19 例が全て読み書きが可能で Wernicke 失語 ではなかったとして, Wernicke 野は言語野ではな くことばの聴き取りに関係しているだけと主張して いることを紹介している。近年この問題は, ことば の聴き取り能力と理解能力との相関を検討すること によって議論されているが, 結果が一致していない。

問題をことばの理解障害を起こす病巣はどこかと して捉えると, Dronkersら（2004）は詳細な言語 理解検査の成績と病巣との関係から, 単語の理解障 害を起こす病巣は中側頭回であると主張している。 またDeWittら（2013）は, 単語の理解領野は上側 頭回前部であるとしてこの領域を聴覚単語形態野 (Auditory Word Form Area：AWFA）と命名し，そ の範囲を側頭極から 35 ～70mm としている。さら にMesulam ら（2015）は原発性進行性失語患者の 詳細な分析から, 単語の理解障害は, Wernicke 野 の損傷では起こらず，側頭極を含む側頭葉前部の損 傷で起こるとしている。このように，単語の理解障 害を起こす病巣としてはさまざまな部位が挙げられ ているが, 古典論のいう Wernicke 野 (上側頭回後部) は，損傷によっては単語の理解障害が起きない (Binder 2015) とまで書かれている。

\section{III. 弓状束の真実?}

Broca 野と Wernicke 野とを弓状束が結んでいると する古典論のモデルは，ヒトの脳には長連合線維を 正確に捉える方法がないなかでの推測にすぎなかっ た。しかし，今世紀に入ってDTIが出現すると， 生きているヒトの線維結合を無侵襲で視覚化できる ようになり，さまざまな線維結合を明らかにしたと する結果が次々と報告されるようになった。しかし， DTIには, 一定の軸索が纒まって走っている部分 は捉えられるが，複数の線維が交叉したり近くを 
走っている場合は区別することができず，また軸索 の起始部と終止部は捉えられないという致命的な欠 陥があり, 報告されている結果には一致しない面も 多く混乱を呈している。弓状束に関しても, 古典論 の主張が確認されたとする報告（Catani ら 2005 な ど）がある一方で，それを否定する結果も多く (Bernalら 2010, Dickら 2012 など), なかには, 同じ研究者が異なる結果を報告している場合もある (Catani ら 2005, 2008 など)。その後, 起点領域を 増やすなどDTIの改良が種々試みられ，またDTI を補う手段として安静時機能的結合法 (resting state functional connectivity : RSFC) や解剖（こ れも方法が改良されている)（Martinoら 2011）を 並行して行って線維連絡を追及するなど, DTIの 結果の信頼性を高努力が続けられている。こう したなかで Yagmurlu ら（2016）は, 健常成人 2 例 の DTI の結果と, 固定脳 25 個と非固定脳 3 個の解 剖の結果を報告している。DTI が登場してから 10 年以上が経過した時点でまだこれだけの数の脳の解 剖が必要とされることは, 現時点でも DTI の信頼 性に問題があることを研究者自身が認めているとみ ることができる。最近は, 言語機能を脳内のネット ワークとして説明する試みが種々なされている (Friederici 2011 など) が, それ以前に, ネットワー クに登場する弓状束を始めとする各種の線維結合の 実態が何処まで明らかにされているのかを明確にす る必要があると思われる。

\section{文 献}

1 ) Bernal, B. \& Altman, N. : The connectivity of the superior longitudinal fasciculus : a tractography DTI study. Magn. Reson. Imaging., 28 : 217-225, 2010.

2 ) Binder, J. R. : Wernicke aphasia : A disorders of central language processing. In : Neurological Foundations of Cognitive Neuroscience (ed. D’Esposito, M.). MIT Press, Cambridge, 2003, pp. 176-238.

3 ) Binder, J. R. : The Wernicke area : Modern evidence and a reinterpretation. Neurology, $85:$ 2170-2175. 2015.

4 ) Bogen, J. E. \& Bogen, G. M. : Wernicke's region-where is it? Ann. N. Y. Acad. Sci., 290 : 834-843, 1976.

5 ) Braak, H. : Architectonics as seen by lipofuscin stains. In : Cerebral Cortex, Vol. 1, Cellular Organization of the Cerebral Cortex (eds. Peters, A. \& Jones, E. G.). Plenum Press, New York-London, 1984, pp59-104.

6 ) Brown, E. C., Jeong, J. W., Muzik, O., et al. : Evaluating the arcuate fasciculus with combined diffusin-weighted MRI tractography and electrocorticography. Hum. Brain.
Mapp., 35 : 2333-2347, 2014.

7 ) Catani, M., Jones, D. K. \& ffyche, D. H. : Perisylvian language networks of the human brain. Ann. Neurol., $57: 8$ $-16,2005$.

8 ) Catani, M. \& Thiebaut de Schotten, M. : A diffusion tensor imaging tractography atlas for virtual in vivo dessection. Cortex, $44:$ 1105-1132, 2008.

9 ) Chang, S. E., Horwitz, B., Ostuni, J., et al. : Evidence of left inferior frontal-premotor structural and functional connectivity deficits in adults who stutter. Cereb. Cortex, 21 : 2507-2518, 2011.

10) DeWitt, I. \& Rauschecker, J. P. : Wernicke's area revisited : parallel streams and word processing. Brain. Lang., $127:$ 181-191, 2013.

11) Dick, A. S. \& Tremblay, P. : Beyond the arcuate fasciculus : consensus and controversy in the connectional anatomy of language. Brain, $135:$ 3529-3550, 2012

12) Dronkers, N. F., Wilkins, D. P., Van Valin, R. D. Jr., et al. : Lesion analysis of the brain areas involved in language comprehension. Cognition, 92 : 145-177, 2004.

13) Flinker, A., Korzeniewska, A., Shesthy, A. Y., et al. Redefining the role of Broca's area in speech. Proc. Natl. Acad. Sci. U. S. A., 112 : 2871-2875, 2015.

14) Frey, S., Campbell, J. S. W., Pike, G. B., et al. : Dissociating the human language pathways with high angular resolution diffusion fiber tractography. J. Neurosci., 28 : 11435-11444, 2008.

15) Friederici, A. D. : The brain basis of language processing : From structure to function. Phisiol. Rev., 91 : 13571392, 2011.

16）岩田 誠, 河村 満, 酒井邦嘉, ほか：Leborgne 報告 から 150 年一人間の本質をみつめた Broca（前編）. Brain and Nerve, 63 : 1087-1098, 2011.

17) Lemaire, J. J., Golby, A., Wells, W. M. 3rd., et al. : Extended Broca's area in the functional connectome of language in adults : combined cortical and subcortical single-subject analysis using fMRI and DTI tractography. Brain Topogr., 26 : 428-441, 2013.

18) Long, M. A., Katlowitz, K. A., Svirsky, M. A., et al. : Functional segregation of cortical regions underlying speech timing and articulation. Neuron, $89:$ 1187-1193, 2016.

19) Margulies, D. \& Petrides, M. : Distinct parietal and temporal connectivity profiles of ventrolateral frontal areas involved in language production. J. Neurosciences, 33 : 16846-16852, 2013.

20) Martino, J., De Witt Hamer, P. C., Vergani, F., et al. : Cortex-sparing fiber dissection : an improved method for the study of white matter anatomy in the human brain. J. Anat., 219 : 531-541, 2011.

21) Mesulam, M. M., Thompson, C. K., Weintraub, S., et al. : The Wernicke conundrum and the anatomy of language comprehension in primary progressive aphasia. Brain, 
$138: 2423-2437,2015$.

22) 西尾慶之, 森 悦郎: 左右前頭葉の機能的差異. Brain Medical, 23 : 155-162, 2011.

23) Penfield, W. \& Roberts, L. : Speech and Brain Mechanisms. Prinston University Press, New Jersey, 1959.

24) Tremblay, P. \& Dick, A. S. : Broca and Wernicke are dead, or moving past the classic model of language neurobiology. Brain. Lang., 162 : 60-71, 2016.

25) Yagmurlu, K., Middlebrooks, E. H., Tanriover, N., et al. : Fiber tracts of the dorsal language stream in the human brain. J. Neurosurg., $124:$ 1396-1405, 2016.

26) Yeterian, E. H., Pandya, D. N., Tomajuolo, F., et al. : The cortical connectivity of the prefrontal cortex in the monkey brain. Cortex, $48: 58-81,2012$.

\section{Abstract}

\section{The truth of Broca's area, Wernicke's area and arcuate fasciculus Juro Kawachi*}

Despite Broca difined Broca's area (Brodmann area-44, 45) as the seat of articulate speech, most aphasiologists defined Broca's area as the language center. Whether Broca's area has articulate function is still mystery. While Wernicke difined Wernicke's area (posteruior part of superior temporal lobe) as the seat of auditory image of language, many aphasiologists defined Wernicke's area as the seat of language comprehension. The true function of Wernicke's area and the seat of language comprehension are still controrversial. Scince the advent of DTI, many studies reported the long association fibers including arcuate fasciculus in the humann brain. Although DTI studies can provide evidence about majour fibers, current methodological limitations do not allow pricise deliniation of the origins and terminations of these fibers. So, the connectivity of arcuate fasciculus is still controversial. 